\title{
Radiographic diagnosis of traumatic urethrorectal fistula in dog
}

\author{
Diagnóstico radiográfico de fístula uretroretal traumática em cão
}

\author{
Maria Cristina Ferrarini Nunes Soares Hage ${ }^{I^{*}}$ Tatiana Schmitz Duarte $^{\mathrm{I}}$ \\ Telma Rocha Tavares ${ }^{I}$ Lissandro Gonçalves Conceição ${ }^{I}$ \\ Ricardo Junqueira Del Carlo ${ }^{\mathrm{I}}$ Vinícus Zavan ${ }^{\mathrm{I}}$
}

\begin{abstract}
A dog with abdominal trauma had an urethrorectal fistula and secundary bilateral hidronephrosis and hydroureter, identified by urethrocistography and excretory urography. According to our researches, only two cases of traumatic urethrorectal fistula had been reported until now in veterinary medicine.
\end{abstract}

Key words: excretory urography, radiology, urethra, urethrocistography, urinary tract.

\section{RESUMO}

Um cão com trauma abdominal desenvolveu fístula uretroretal, hidronefrose e hidroureter bilaterais secundários, identificados por uretrocistografia e urografia excretora. $\mathrm{Na}$ literatura veterinária, há somente dois casos de fístulas uretroretais traumáticas descritos até o momento.

Palavras-chave: urografia excretora, radiologia, uretra, uretrocistografia, trato urinário.

Urethrorectal fistulas are uncommonly reported in veterinary medicine with only 13 cases reported in dogs (CRUSE et al., 2009). The condition can be congenital or acquired (AGUT et al., 2006; PECHMAN, 2007). Congenital urethrorectal fistulas are usually associated with other anorectal abnormalities. Acquired fistulas might be the result from trauma, surgery, infection or neoplasia (AL-ALI et al., 1997). Of the 13 cases, 11 were suspected to be congenital in nature (CRUSE el al., 2009).
The diagnosis of this kind of fistula is challenging (CRUSE et al., 2009). The most confident clinical sign is fecaluria (void urina via the rectum) (ALALI el al., 1997). Conventional radiographs, double contrast cystography, pneumocystography, colonoscopy, urethroscopy (AL-ALI et al., 1997), computed tomography and magnetic resonance imaging have already been used to diagnosis this condition (CRUSE et al., 2009).

Although spontaneous healing has been observed in posttraumatic urethrorectal fistulas in human medicine, surgical intervention was necessary in most reported cases. Urethrorectal fistula is considered one of the most difficult fistulas to treat (AL-ALI et al., 1997). The aim of this paper was to describe an uncommon case of traumatic urethrorectal fistula diagnosed by contrasted radiographic techniques.

A 3-year-old sexually intact mongrel dog weighing $20 \mathrm{~kg}$ was admitted to the veterinary medical teaching hospital because of anorexia, anuria, vomiting, intense abdominal pain and abdominal hematoma. It was observed urethral obstruction, azotemia, leukocytosis and trombocytopenia. The dog was submitted to surgical procedure and a hemorragic, harsh and fully bladder was found. Obstructing the urinary outflow, around the trigone and proximal portion of the urethra, there was a hemorrhagic and

\footnotetext{
'Departamento de Veterinária, Universidade Federal de Viçosa (UFV), 36570-000, Viçosa, MG, Brasil. E-mail: crishage@ufv.br. "Autor para correspondência.
} 
edematous mass, which was impossible to be removed surgically. A Foley catheter was implanted by cystostomy while a natural urethral desobstruction was expected. After fifteen days, the catheter was removed and it was observed adhesions between omentum, rectum and bladder. At this point the dog presented liquid diarrhea and urinary incontinence. The urine culture showed infection by Escherichia coli.

Conventional and urethrocistography radiographs were obtained. Gases were identified in large intestine by the conventional radiographs (Figure $1 \mathrm{~A}$ and $\mathrm{B})$. After that, $30 \mathrm{ml}$ of an ionic iodinated contrast media (sodium amidotrizoate associated with meglumine amidotrizoate ${ }^{\mathrm{a}}$ ) was diluted with $30 \mathrm{ml}$ of physiological solution $0.9 \%$ in three $20 \mathrm{ml}$ syringes. The first syringe was connected to an urethral catheter and its lumen was filled in. The tip of the urethral catheter, about $2 \mathrm{~cm}$, was inserted into the previosly cleaned distal penile urethra. A cotton swab was held in the glans to prevent reflux of the contrast media. A veterinarian adequately protected from radiation injected the first $40 \mathrm{ml}$ of the contrast. A latetolateral radiography was performed during injection of the third syringe contents. The urethral catheter was removed and a ventrodorsal radiography was subsequently obtained. After contrast introduction the urethra was

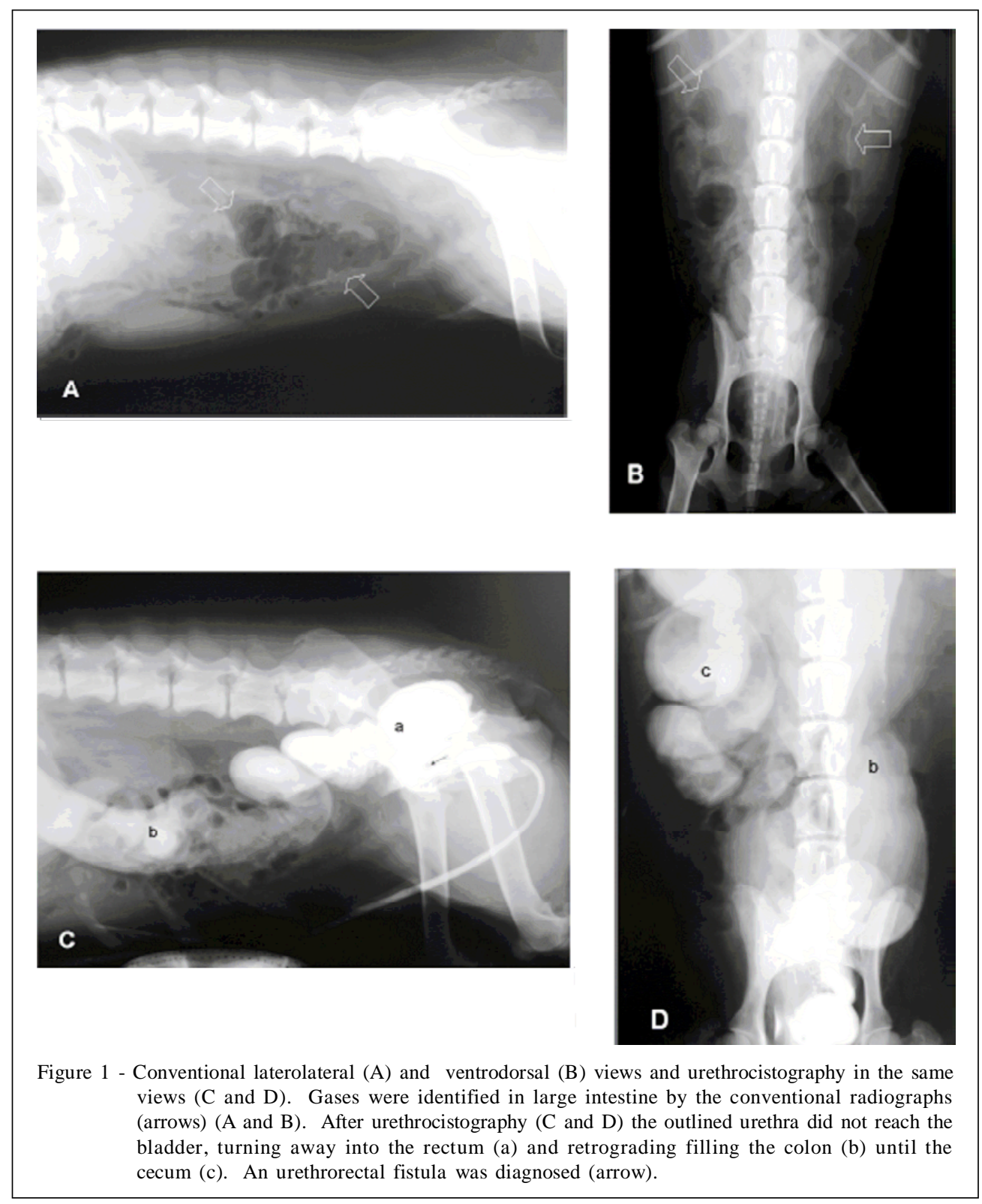

Ciência Rural, v.41, n.5, mai, 2011. 
outlined but it did not reach the bladder, turning away into the rectum and retrograding filling the colon until the cecum. Due to these radiographic findings a urethrorectal fistula was diagnosed (Figure 1C and D).

After few days, an excretory urography was performed as an additional imaging study. For this technique food was withheld for 24 hours. The hydration and the kidney function were verified as normal. Conventional laterolateral and ventrodorsal views were obtained. A cephalic venous catheter was placed and an ionic iodinated contrast media (sodium amidotrizoate associated with meglumine amidotrizoate $^{\mathrm{a}}$ ) was given by intravenous bolus injection at the dose of $2 \mathrm{ml} \mathrm{kg}^{-1}$. The catheter was maintained until the end of the procedure with slow administration of physiological solution $0,9 \%^{\mathrm{b}}$ to provide a readily accessible route in the event of systemic reactions. Radiographs were obtained immediately and 5,20, and 40 minutes after the injection of the contrast media. This study was able to identify dilatation and distortion of the kidneys pelvis and recesses with abnormal distention of the ureteres. These findings were compatible with bilateral hydronephrosis and hydroureter (Figure 2A and B). A second urethrocistography confirmed the fistula (Figure 2C and D).

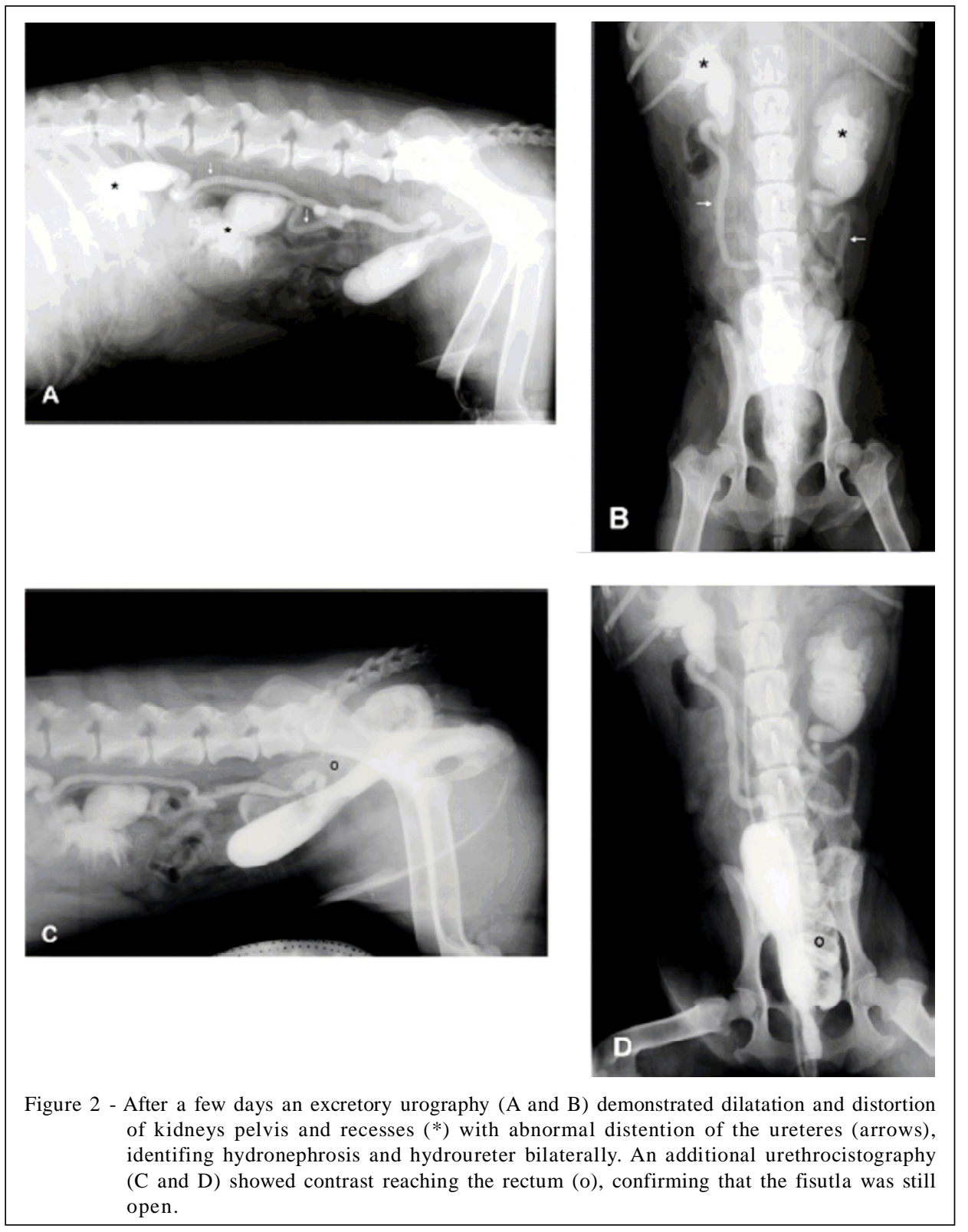

Ciência Rural, v.41, n.5, mai, 2011. 
Spontaneous healing of urethrorectal fistulas is rare, even after cutaneous fecal and urinary diversion (deviation of the colon and ureteres to skin). As a result, numerous surgical procedures have been described (MUNÕZ et al., 1998); however, none gained acceptance as a gold-standard in human medicine, and new procedures have still been described (CHIRICA et al., 2006).

The surgery was planned having in mind the feasibility of the postoperative maintenance of a dog. Cutaneous fecal and urinary diversion was then considered unviable. The aim of the planned surgical procedure was to provide permanent urinary diversion to the colon because preservation of the bladder was impossible. This choice was done cognizant of the risks of ascending pyelonephritis (NUNOO-MENSAH et al., 2008).

The dog was submitted to a bilateral uretherocolic anastomosis (deviation of the ureteres into the colon), reduction of the fistula (fistula closure), and total cystectomy (resection of the bladder), but he died in the postoperative period. The dog was not submitted to necropsy, but the cause of death could be related to his poor clinical condition and sepsis of urinary origin.

The use of the contrasted radiograhic techniques, in this case, made possible the identification, location and extension of the urethorectal fistula and secondary urinary alterations. Therefore, the radiographic finds were essential for surgical planning of this challenging procedure of poor prognosis.

\section{FONTES DE AQUISIÇÃO}

a - Urografina $292^{\circledR}$ - Schering do Brasil, Química e Farmacêutica Ltda - Rua Cancioneiro de Évora, 255/339/383, 04708-010, São Paulo, SP.

b - Solução Fisiológica de Cloreto de Sódio a 0,9\% - Equiplex Indústria Farmacêutica - Rua Thubérgia Qd. K, 233, 74986710, Aparecida de Goiânia, GO.

\section{COMITÊ DE ÉTICA E BIOSSEGURANÇA}

Número do protocolo: 61/2010.

\section{REFERENCES}

AGUT, A. et al. A urethrorectal fistula due to prostatic abscess associated with urolithiasis in a dog. Reproduction in Domestic Animals, v.41, n.3, p.247-250, jun. 2006. Available on: <http://novo.periodicos.capes.gov.br>. Accessed: Out. 10, 2010. doi:10.1111/j.1439-0531.2006-00680.x.

AL-ALI, M. et al. Experience with 30 posttraumatic rectourethral fistulas: presentation of posterior transsphincteric anterior rectal wall advancement. Journal of Urology, v.158, n.2, p.421-424, aug. 1997. Available on: 〈http://sciencedirect.com>. Accessed: Out. 10, 2010. doi:10.1016/S0022-5347(01)64493-8.

CHIRICA, M. et al. Coloanal sleeve anastomosis (soave procedure): the ultimate treatment option for complex rectourinary fistulas. Diseases of the colon $\&$ rectum, v.49, n.9, p.1379-1383, sept, 2006. Available on: <http:// novo.periodicos.capes.gov.br> Accessed: Jan. 12, 2011. doi:10.1007/s10350-006-0636-9.

CRUSE, A.M. et al. Use of computed tomography (CT) scanning and colorectal new methylene blue infusion in evaluation of an English Bulldog with a rectourethral fistula. Journal of Veterinary Internal Medicine, v.23, n.4, p.931-934, jul/aug, 2009. Available on: <http://novo.periodicos.capes.gov.br>. Accessed: Out. 10, 2010. doi: 10.1111/j.19391676.2009.0320.x.

MUNÕZ, M. et al. Management of acquired rectourinary fistulas - outcome according to cause. Disases of the colon \& rectum, v.41, n.10, p.1230-1238, oct, 1998. Available on: <http:// novo.periodicos.capes.gov.br>. Accessed: Jan. 12, 2011. doi:10.1007/BF02258219.

NUNOO-MENSAH, J.W. et al. Management of acquired rectourinary fistulas: how often and when is permanent fecal or urinary diversion necessary? Diseases of the colon \& rectum, v.51, n.7, p.1049-1054, jul, 2008. Available on: <http:// novo.periodicos.capes.gov.br>. Accessed: Jan. 12, 2011. doi:10.1007/s10350-008-9303-7.

PECHMAN JR, R.D. The urethra. In: THRALL, D.E. (Ed.). Textbook of veterinary diagnostic radiology. 5.ed. St. Louis: Saunders Elsevier, 2007. p.725-728. 